\title{
DATA PENDUDUK DAN E-KTP
}

\author{
Sita Dewi, Dwi Listyowati, Bertha Elvy Napitupulu \\ STIE Jayakarta \\ sitadewi.27@gmail.com \\ dwilist.2661@yahoo.com \\ bertha.napitupulu@yahoo.com
}

\begin{abstract}
Abstrak
Sumber utama data penduduk adalah dari SENSUS Penduduk, registrasi dan sampel survey. Registrasi mencatat hal-hal yang penting saja dalam kehidupan seseorang misalnya kelahiran, kematian, perkawinan, pindah. Registrasi disebut juga sebagai statistic vital. Salah satu contoh registrasi adalah adanya KTP (kartu tanda penduduk) yang sejak tahun 2010 Indonesia memberlakukan KTP elektronik (E-KTP).
\end{abstract}

\section{PENDAHULUAN}

Data adalah nilai dari variable. Data penduduk berarti nilai dari variable penduduk. Variabel penduduk terdiri dari variable umur, jenis kelamin, status perkawinan, pendidikan, tempat tinggal dan yang lainnya, yang mencirikan penduduk tersebut.

Untuk memperoleh data penduduk setiap Negara mempunyai cara-cara tersendiri. Banyak Negara melakukan SENSUS Penduduk untuk mengetahui data penduduknya. Indonesia juga melaksanakan SENSUS Penduduka. SENSUS pertama di Indonesia diselenggarakan pada tahun 1955 dan yang terakhir tahun 2010. SENSUS Penduduka akan diselenggarakan lagi pada tahun 2020. Selain SENSUS Penduduk, pengumpulan data penduduk yang paling sederhana adalah mencatat langsung cirriciri penduduk tersebut, misalnya pencatatan kelahiran di gereja. Di Indonesia pencatatan data penduduk secara langsung dilakukan di kelurahan. Kelurahan mencatat kelahiran, kematian, pernikahan, perpindahan penduduk. Data penduduk dari kelurahan dilaporkan ke catatan sipil. Bukti bahwa warga Negara Indonesia sudah tercatat di catatan sipil adalah diterbitkannya NIK (Nomor Induk Kependudukan). Bagi yang telah berumur 17 tahun atau yang telah menikah akan diteritkan KTP (Kartu Tanda Penduduk), yang sejak tahun 2010 KTP di Indonesia menjadi KTP elektronik.

Jadi Indonesia melakukan pengumpulan data penduduk melalui SENSUS PENDUDUK, Registrasi dan juga Sampel Survei. Ke tiga cara ini mempunyai tujuan dan aturan yang berbeda.

Data penduduk yang akurat dapat digunakan oleh pemangku kebijakan untuk menentukan kebijakan, sehingga bermanfaat bagi penduduknya. 


\section{SUMBER DATA PENDUDUK}

Ada tiga sumber utama data penduduk yaitu SENSUS PENDUDUK, Registrasi dan Sampel Survei. Di Indonesia ke tiga sumber data ini ada. Indonesia melakukan SENSUS PENDUDUK setiap 10 tahun sekali. Registrasi dapat dilakukan setiap saat (di kantor kelurahan) dan Sampel Survei dilakukan sesuai dengan keperluan, misalnya SAKERNAS (untuk tenaga kerja), SUSENAS (untuk memetakan keadaan Ekonomi) ataupun SUPAS.

Setiap sumber data penduduk, mempunyai kelebihan dan kekurangan. Dengan mengetahui sumber-sumber data penduduk dapat diketahui kondisi penduduk secara umum ataupun secara khusus.

Pengelompokkan tiga sumber data utama data penduduk adalah berdasarkan proses pengumpulan datanya. Data-data tersebut adalah data primer atau data asli, yaitu data yang dikumpulkan oleh orang/ organisasi dan diolah serta disajikan oleh orang/oraganisasi tersebut.

\subsection{SENSUS Penduduk}

Tujuan dilakukannya SENSUS Penduduk adalah untuk menghitung jumlah orang/penduduk di suatu wilayah dalam hal ini yang dimaksud wilayah adalah Negara.

Menurut Perserikatan BangsaBangsa (PBB) dalam Principles and Recomandation for National Population Cencus (Statistical Papers, Series M No 7,158 ), Sensus penduduk adalah keseluruhan proses pengumpulan, menghimpun dan menyusun dan menerbitkan data-data demografi, ekonomi dan social yang menyangkut semua orang pada waktu tertentu di suatu Negara atau suatu wilayah.

Dalam Sensus Penduduk melibatkan semua orang sebagi responden dan dilakukan dalam waktu tertentu dan secara serentak dan juga pada suatu wilayah tertentu, yaitu Negara tertentu. Jadi dalam SENSUS Penduduk terdapat 3 ketentuan utama, yaitu:

1. Semua orang

2. Waktu tertentu

3. Wilayah tertentu

Ke tiga ketentuan inilah yang membedakan SENSUS dengan pengumpulan data yang lain.

Data yang dikumpulkan dalam SENSUS meliputi demografi, ekonomi dan social. Rincian data demografi, ekonomi dan social tergantung dari kebutuhan dan kepentingan SENSUS tersebut dilaksanakan di suatu wilayah tertentu.

SENSUS Penduduk di Indonesia talah dilaksanakan sejak tahun 1955, sampai dengan SENSUS Penduduk yang terakhir tahun 2010, Indonesia telah melaksanakan 7 kali SENSUS Penduduk, yaitu pada tahun 1955, 1961, 1971, 1980, 1990, 2000, dan 2010. SENSUS Penduduk di Indonesia dilaksanakan setiap 10 tahun sekali sesuai dengan Peraturan Pemerintah no 6/1960 dan no 7/1960 (https/www BPS.go.id). Sehingga SENSUS Penduduk Indonesia berikutnya akan diselenggarakan pada tahun 2020.

Pada setiap SENSUS Penduduk yang diselenggarakan di Indonesia tujuan 
utamaya adalah untuk menghitung berapa besarnya jumlah penduduk Indonesia. Berdasrkan SENSUS Penduduk Indonesai terakhir tahun 2010, jumlah penduduk Indonesia adalah 237.641.326 jiwa. Jumlah penduduk yang besar, yaitu urutan nomor 4 jumlah penduduk terbesar di dunia.

Metode SENSUS Penduduk atau metode pengumpulan data pada SENSUS Penduduk yang dilakukan di Indonesia adalah metode canveser. Dalam metode ini petugas SENSUS yang melakukan pengisian kuesioner (daftar pertanyaan) dengan cara mendatangi dan mewawancarai penduduk secara langsung. Hal ini dilakukan, untuk menghindari kealahan pengisian atau apabila penduduk tidak mengerti maksud dari pertanyaan yang ada. Dalam SENSUS Penduduk Indonesia tahun 2010, jumlah pertanyaan sudah cukup banyak, karena selain untuk mengetahui jumlah penduduk Indonesia, SENSUS penduduk tahun 2010 juga mempunyai tujuan yang lain, misalnya cakupan KB (keluarga Berencara) dan kesehatan.

\subsection{Registrasi}

Registrasi adalah keterangan-keterangan tentang peristiwa penting yang terjadi pada seseorang yang dapat merubah status sipil orang tersebut mulai dari lahir sampai dengan mati. Registrasi dimulai dari kelahiran. Dalam perjalanan hidupnya peristiwa-peristiwa penting yang dapat merrubah status sipil orang tersebut dicatat, seperti perkawinan, perceraian, adopsi anak, pindah, sampai kematian orang tersebut. Registrasi dapat juga disebut sebagai statistic vital, karena yang dicatat hal-hal yang penting saja dalam kehidupan seseorang.

Karena yang dicatat adalah kejadian lahir, mati, kawin, pindah dan sebagainya, maka registrasi berjalan terus menerus mengikuti perjalanan individunya. Hal ini menggambarkan perubahan individu secara terus menerus.

Dalam registrasi individu dalam hal ini adalah penduduk, yang aktif melaporkan kejadian-kejadian yang dialaminya. Yang melakukan pencatatan kejadian-kejadian atau perubahan-perubahan kejadian yang dialami individu adalah suatu badan tertentu yang ditunjuk. Badan yang mencatat kejadian-kejadian ini dapat sama atau berbeda.

Di Indonesia registrasi dapat dilakukn di Kantor Kependudukan dan Catatan Sipil atau di Kantor Kelurahan, sebagai wakil pemerintah yang paling dekat ke penduduk. Kantor kelurahan mengurus segala keperluan penduduk. Ada pula registrasi yang dilakukan di badan lain misalnya KUA (Kantor Urusan Agama) untuk pencatatan pernikahan.

Untuk pencatatan kelahiran, kematian, migrasi (pindah) dilakukan di kantor kelurahan, yang nantinya akan diteruskan ke kantor Kependudukan dan Catatan Sipil. Data penduduk disimpan di kantor kelurahan. Dari kantor keluranan ini dapat diketahui jumlah penduduk di wilayah tersebut, jumlah yang lahir, jumlah penduduk yang pindah dan juga jumlah penduduk yang mati. 


\subsection{Survei}

Survei yang dimaksud di sini adalah dalam skala besar atau skala nasional. Jadi survey ini seperti SENSUS. Survei dilaksanakan berdasarkan keperluan Negara. Adapun tahapan kerja dan keterangan yang dikumpulkan hampir sama dengan SENSUS. Yang membuat Survei dan SENSUS berbeda adalah sasaran respondennya. Dalam SENSUS repondennya adalah semua penduduk sedangkan dalam Survei responennya tidak semua penduduk, tetapi penduduk dengan criteria tertentu sesuai dengan tujuan survey tersebut.

Perbedaan lain antara SENSUS dan survey adalah pada waktu pelaksanaannya. SENSUS dilakukan pada jangka waktu tertentu. Seperti di Indonesia SENSUS Penduduk Indonesia dilakukan setiap 10 tahun sekali. Sedangkan Survei dapat dilakukan sewaktuwaktu, sesuai dengan kebuthan.

SENSUS dan Survei diharapkan saling melengkapi. Di Indonesia, Survei yang dilakukan secara nasional melengkapi SENSUS Penduduk Indonesia. Survei yang dilakukan secara nasional di Indonesia mislanya SUPAS, SUSENAS, SAKERNAS. Misalnya Sensus Penduduk Indonesia tahun 2000 lalu kemudian SENSUS Penduduk Indonesia tahun 2010. Dari SENSUS Penduduk Indonesia tahun 2000 diketahui jumlah penduduk Indonesia tahun 2000 dn dari SENSUS Penuduk Indonesia tahun 2010 diketahui jumlah penduduk Indonesia tahun 2010. Di antara kedua SENSUS Penduduk tersebut, terdapat SUPAS 2005, dimana SUPAS juga menghitung jumlah penduduk. Jadi jumlah penduduk
Indonesia tidak saja terpantau dalam jangka 10 tahun sekali, tetapi bias juga terpantau dalam jangka lima tahun sekali.

\section{KARTU TANDA PENDUDUK ELEKTRONIK (E-KTP)}

Penduduk Indonesia mencatatkan kejadian-kejadian kehidupannya seperti kelahiran, kematian, pindah, ke kantor kelurahan. Kantor kelurahan adalah instansi atau badan milik pemerintah Republik Indonesia yang bertugas meregistasi penduduk Indonesia di suatu wilayah tertentu. Pencatatan yang dilakukan di kelurahan juga merupakan pencatatan cirri-ciri penduduk seperti nama, tempat tanggal lahir (kelahiran), alamat, jenis kelamin, agama, status perkawinan, pendidikan dan juga pekerjaan. Catatan ini diperlukan oleh kelurahan untuk mengetahui identitas penduduk di wilayahnya. Sebagai bukti catatan-catatan ini sudah dilakukan oleh kelurahan, maka diterbitkan kartu kelluarga. Kartu ini berisi informasi penduduk yang merupakan satu keluarga. Anggota keluarga yang telah berumur 17 tahun ke atas atau telah menikah, melapor kembali ke kelurahan untuk dibuatkan Kartu Tanda Penduduk (KTP). Kartu Tanda Pendudukk atau KTP adalah identitas resmi penduduk Republik Indonesia. Jadi setiap warga Negara Indonesia (WNI) yang telah berusia 17 tahun atau telah menikah harus mempunyai Kartu Tanda Penduduk (KTP).

Di Kartu Tanda Penduduk terdapat informasi mengenai NIK (nomor Induk Kependudukan), nama lengkap, tempat tanggal lahir, jenis kelamin, agama, status, golongan darah, alamat lengkap, pekerjaan, foto diri, tanggal keluarnya KTP dan tanda tangan pejabat 
yang berwenang dalam hal ini adalah lurah. Informasi yang tertera pada Kartu Tanda Penduduk (KTP) cukup lengkap. Khusus untuk NIK (Nomor Induk Kependudukan), diperoleh sejak kelahirannya dilaporkan (wikipedia.org)

Kartu Tanda Penduduk sebelum tahun 2010 dicetak pada kertas dan kemudian di laminating. Pada masa itu system basis data kependudukan yang dimiliki pemerintah (Kementrian Dalam Negeri, Direktorat Jenderal Kependudukan dan Catatan Sipil) belum baik. Penduduk yang memohon untuk dibuatkan Kartu Tanda Penduduk (KTP) selalu dilayani untuk dibuatkan, tanpa memeriksa apakah orang yang bersangkutan telah mempunyai Kartu Tanda Penduduk atau belum. Sehingga pada masa itu seorang penduduk dapat mempunyai Kartu Tanda Penduduk (KTP) lebih dari satu (KTP ganda), yang akhirnya sering disalahgunakan.

Pada tahun 2010 ppemerintah Republik Indonesia memulai memberlakukan Kartu Tanda Penduduk Elektronik atau biasa disebut E-KTP. Untuk memulai pembuatan E-KTP ini pemerintah, dalam hal ini adalah Kementrian Dalam Negeri, Direktorat Jenderal Kependudukan dan Catatan Sipil, mealukan pendataan ulang penduduk Indonesia yang telah mempunyai KTP. Data pada KTP lama di input kembali, ditambah dengan data sidik jari dan iris mata, foto dan tanda tangan langsung. Proses ini disebut proses perekaman. Hasil perrekaman ini yang berupa data penduduk disimpan di data base Kementrian Dalam Negeri Direktorat Jenderal Kependudukana dan Catatan
Sipil. Proses perekaman ini memakan waktu cukup lama, karena banyaknya jumlah penduduk Indonesia, Secara bertahap penduduk yang membuat KTP kemudian (baru berusia 17 tahun) juga direkam datanya. Hingga tahun ini proses perekaman data penduduk telah mencapai lebih dari $90 \%$. Setelah proses perekaman selesai, maka KTP elektronik dapat diterbitkan, KTP elektronik atau EKTP adalah dokumen kependudukan yang memuat system keamanan atau pengendalian baik dari sisi administrasi ataupun teknologi informasi dengan berbasis pada database kependudukan nasional (Indonesia.go.id).

Apa keunggulan diberlakukannya E-KTP? Dengan diberlakukannya E-KTP setiap penduduk yang telah memiliki KTP namanya terdata satu kali, artiny tidak aka nada lagi KTP ganda. Dengan berlakunya E-KTP, data penduduk Indonesia yang telah mempunyai KTP telah tersimpan dalam database penduduk yang disebut data kependudukan. Data kependudukan ini dapat dimanfaatkan oleh lembaga atau instansi pemerintah lainnya yang membutuhkan, misalnya kepolisian, Komisi Pemberatasan Korupsi (KPK), BPJS dan yang lainnya.

Data kependudukan ini akurat dan aman. Setiap orang ataupun lembaga ataupun instansi dapat mengakses data kependudukan hanya dengan mengimput NIK (Nomor Induk Kependudukan) seseorang (Kementrian Dalam Negeri, Direktorat Jenderal Kependudukan dan Ctatan Sipil, 2013). Orang ataupun lembaga ataupun instansi yang mengakses atau memanfaatkan data kependudukan dapat terpantau oleh Direktorat Jenderal 
Kependudukan dan Catatan Sipil, sehingga dapat mencegah tindakan criminal.

Untuk semenata ini data kependudukan hanya berisi orang-orang/ penduduk yang telah mempunyai E-KTP. Data orang/penduduk yang belum mempunyai E-KTP dapat juga terlihat bila data orang yang memiliki E-KTP dibuka. Sekarang ini sedang disosialisakikan pembuatan Kartu Identitas Anak (KIA) . KIA berfungsi seperti KTP, tapi berlaku untuk orang/penduduk yang belum berusia 17 tahun.

Tidak seperti KTP sebelumnya yang harus diganti per lima tahun sekali, maka E-KTP berlaku seumur hidup sejak tahun 2016 (Kementrian Dalam Negeri, 2016). Hal ini menhemat biaya pembuatan KTP. Tetapi orang yang memegang E-KTP dituntut aktif melaporkan dirinya ke kantor kelurahan sebagai instansi pemerintah yang paling dekat dengan lingkungannya, apabila ada perubahan data diri.

Dengan adanya data kependudukan yang akurat dan baik, serta mudah diakses tentu akan memudahkan pemerintah mengambil kebijakan, sehingga dapat membantu meningkatkan pembangunan.

\begin{abstract}
DAFTAR PUSTAKA
Direktorat Jenderal Kependudukan dan Catatan Sipil Kementrian Dalam Negeri Republik Indonesia, Data Kependudukan, bahan Seminar Nasional Demografi 100 tahun Kemerdekaan Indonesia, Depok 4 Desember 2017.
\end{abstract}

https/www.BPS.go.id., SENSUS Penduduk di Indonesia

https/www.dukcapilkemendagri.go.id., Dengan Input NIK 2 menit Data Pemilik E-KTP muncul, Desember 2013

https/www.dukcapilkemendagri.go.id., KTP-el Berlaku Seumur Hidup, Januari 2016

https/www.Indonesia.go.id., $\quad K T P$ Elektronik

https/www.wikipedia.org., KTP

United Nation., Principles and Recommendation for National Population Cencus (Statistical Papers Series M No 7.158)

Yunus, Nizam A., Sumber-sumber dan Evaluasi Data Kependudukan, dalam Dasar-dasar Denografi. Jakarta, LDFEUI, 1981. 